However, Hartman limits contemplative existence too narrowly. The limits become especially evident in his discussion of an interpretive passage in the Babylonian Talmud that "uses verbal evidence easily overlooked to observe the phrase 'Lord of Hosts [Zebaoth]' occurs for the first time in the Bible when Hannah, who is childless, prays for a son" (387). The passage Hartman quotes is charged with questions of gender. Yet he does not stoop to ask, Was the passage written by a man or a woman? Why does Hannah pray for a son rather than a child? Does the fact that a woman is the first one to name the Lord of Hosts and to gender him male confer on patriarchy a spurious legitimacy that wouldn't be as effective had the speaker been male? Can Hannah be read as ironic in her submission de jure to male authority? Such questions do not deny the kind of rigorous interpretive interventions Hartman defends and demands and indeed can supplement them. Nor does asking such questions destroy the possibility of a contemplative existence. Rather, they become a precondition for it. Isn't it possible that feminism or women's studies may be another one of the "earthquakes" (paradigm shifts) he claims Freud and the Holocaust were (383)? Unfortunately, Hartman's blindness to the core importance of gender issues (and, by implication, issues of race and class) casts a shadow on the "natural light of reading lodged in every person" that he appeals to in his defense of close readings (386).

\section{CHRIS STROFFOLINO}

State University' of New York, Albany

\section{The Quest for a Name}

\section{To the Editor:}

In response to Hannah Berliner Fischthal's question regarding a name for those engaged in the study of literature (Forum, 110 [1995]: 416), I propose that we revive the noncommittal nineteenth-century term literarian, which means "one engaged in literary pursuits." Granted, in its earlier incarnation the word was tinged with ridicule, as in the $O E D$ illustration, dated 1866 , that refers to a "brood of literarians." But the professional study of literature was in its adolescence then, which may account for the slightly contemptuous attitude toward the profession and the word describing it. The subsequent respectability earned by our now mature profession has overcome the pejorative associations of literarian.

Fischthal would probably feel comfortable working as a literarian, in company with the sociologist and the dramatist with whom she teaches. The word is no more specific about her work than the names of her colleagues' professions are about their work.
Other words offered by contributors to the Forum are admirable. But philologer, recommended by Arvid Sponberg (111 [1996]: 131-32), and its parent philologist, from Lila Harper (131), arrive with too much baggage to be dissociated from their source. Literate, suggested by Keith Fynaardt (131) has the disadvantage of evoking anyone who can read and write. Anglicist, proposed by Sebastian Iragui (Forum, 111 [1996]: 476), on the other hand, limits the field to those in English, which eliminates everybody else in the Modern Language Association. While Iragui notes that Anglicist could be easily assimilated into the Romance languages at least, the word would retain its limited meaning. That is Iragui's intent, of course, but is evidently not what Fischthal had in mind when she called for a word on the same plane as the words describing economists, historians, geographers, architects, and so on. Once a broad term of this nature is accepted, Anglicist would probably work as a subheading, comparable to, say, Americanist or Caribbeanist. One could be a literarian in the broad sense and an Anglicist in the narrow sense.

Literarian replaces naturally the denigrating term literature person and carries the connotations of dignity conferred by historian, mathematician, and so forth. Like those labels, it is broad enough to identify the members of the entire profession without requiring a confession of specialty. Literarian is already part of the English lexis, needing only a brief resuscitative effort to make it functional again. It means what we want it to mean, and it rolls effortlessly off the tongue. What more could we want?

PHYLLIS N. BRAXTON Washington, $D C$

To the Editor:

Prior to my recent retirement from SUNY, Albany, one of my chores in the department of English was the compilation of our annual bibliography. I was struck repeatedly by the fact that, judged by our publications, we constituted not one department but three: literary scholars, creative writers, and teachers of how to teach composition. Each group published in a distinctive array of journals (indeed, even the term journals does not fit the magazines in which the creative writers appeared), and when they wrote books, each group had its own list of publishers. The three segments of the department were a classic case of apples, oranges, and walnuts, a situation, I believe, that is duplicated today at almost every other English department in the country. It is no wonder that our department (like those, I suspect, in other universities) was notoriously fractious, wasting a good bit of time in intradepartmental wrangling. 
Perhaps English departments (traditionally among the largest, if not the largest, on almost every campus) might consider splitting into three separate departments offering three different terminal degrees. (A fourth division, cultural studies, is sometimes cited. However, I do not think that a fuzzy line between cultural and literary studies ought to be drawn, since art has social and political effects that cannot be ignored.) Literary scholars would continue to offer the $\mathrm{PhD}$. Creative writers would grant the MFA. A novel or a collection of poems for the PhD has always been oxymoronic, since such works offer no training in the scholarly rigors associated with the traditional dissertation. Moreover, instead of wasting years in cultivating those skills, creative writers might better leave the university and get on with their writing. Finally, specialists in the teaching of composition would offer the EdD and perhaps move from the college of arts and sciences to the school of education, where many of them already feel at home.

Describing the appropriate degrees for the three parts of Gaul is easy in comparison to finding names for the practitioners in each group. I leave to the creative writers and the specialists in the teaching of composition the search for their titles. But Lila M. Harper, in her letter to the Forum, clearly has literary scholars in mind when she suggests philologist as a title for the members of the English department. Her choice seems eminently sound and is already in use, as she points out, "in the titles of some scholarly journals."

How could the usage she suggests be implemented? The Modern Language Association might take the lead by changing its name to something like the Modern Philology Association. Some regional associations already use variants of this nomenclature. Of course, English departments would have to be distinguished from those devoted to other modern languages. It would be least awkward, if perhaps a trifle arrogant, for Anglophones to preempt the generic term, and other practitioners in the MLA could then call themselves French philologists, German philologists, or whatever.

\section{E. GRENANDER}

State University of New York, Albany

\section{Toni Morrison's Beloved}

To the Editor:

James Berger's interpretation of Toni Morrison's Beloved in conjunction with the Moynihan report demonstrates that interdisciplinary scholarship is almost indispensable in the analysis of race relations ("Ghosts of Liberalism: Morrison's Beloved and the Moynihan Report," 111 [1996]: 408-20). Berger's examination of racist perspectives portrayed in Beloved magnifies the "historical trauma" of racism, which he defines as a "continuing apocalypse" (414). While I do not dispute Berger's interpretation or his critique of liberalism, his biblical allusion to the apocalyptic moment needs reconsideration. I am concerned by the dissociation of the term apocalypse from its religious roots in the Gospels, in general, and in the book of Revelation, in particular. When Berger describes "history and apocalypse" as the "site of trauma" (409), it is important to note that the apocalyptic trauma is merely a passing state that promises moral rectitude and change in the future. This is how I interpret Morrison's repetition of words in the conclusion of Beloved: "It was not a story to pass on."

I agree with Berger that the language of the apocalypse becomes relevant to Morrison's novel with the arrival of the "four horsemen" in Baby Suggs's yard: "The reference to the book of Revelation makes the slave hunters' entrance into Baby Suggs's yard a sign and portent that transcends history ... [because] [t]he apocalyptic event constitutes a pivotal moment that separates what came before from what comes after" (409). When used in a pivotal context, the word apocalypse captures the destruction and the suffering associated with the trauma, but the promise of change is inherent in this destruction. The popular use of apocalypse, which divorces it from its inexorable ties with the gospel of optimism, confines the term within an unjust context that severs all connections with poetic justice. In Revelation, apocalypse implies the ultimate victory of justice and the termination of all forms of evil, including racism. Therefore, it is not surprising that Morrison's concluding chapter emphasizes the promise of change through nature's cycles as "[j]ust weather."

History records events, such as infanticide, in linear time as it correlates temporal logic with natural phenomena. The apocalyptic moment captures the essence of circular time (I am Alpha and Omega, states Revelation) and correlates change with the cyclic order of natural phenomena. The correlation between revelation and death has overtones of hope in the Christian tradition. Christ's death is recorded in the Gospels as a liberating and traumatic moment when the veil of the temple is torn. In this context, Baby Suggs's message to her congregation to love the flesh evokes the gospel of resurrection or faith that transcends the scars of traumatic experiences by revealing a change.

I agree with Berger that in Beloved the "apocalyptic unveiling is not deferred to an uncertain future" $(410)$, because it connects the unending temporal logic of human 